\title{
Nephrin - a biomarker of early glomerular injury
}

\author{
Yogavijayan Kandasamy ${ }^{1,2,3^{*}}$, Roger Smith², Eugenie R Lumbers ${ }^{2}$ and Donna Rudd ${ }^{3}$
}

\begin{abstract}
Nephrin is a $180 \mathrm{KD}$ trans-membrane protein expressed in glomerular podocytes. It was first identified in children with congenital nephrotic syndrome of the Finnish type (NPHS1). Nephrin forms an integral part of podocytes, which —-together with endothelial cells and the basement_form the glomerular filtration barrier. Podocytopathies result in the detection of nephrin in the urine. We reviewed the literature to determine if urine nephrin measurements could become useful as a biomarker to detect early podocyte injury. Our search identified a total of 19 studies that have been published to date. The most common clinical conditions for which urine nephrin analyses were carried out included diabetic nephropathy, glomerulonephritis and pre-eclampsia. Nephrin measurement was carried out using commercially available ELISA kits, the messenger ribonucleic acid real-time polymerase chain Reaction, or electrophoresis. Nephrinuria showed positive correlation with proteinuria and severity of podocyte injury. In two studies, the level of nephrinuria declined in conjunction with clinical improvement in the patient following immunosuppressive treatment. Currently, there is no published data on the value of measuring urinary nephrin in pediatric patients.
\end{abstract}

Keywords: Nephrin, Nephrinuria, Podocytopathy, Glomerular injury, Biomarker

\section{Introduction}

Congenital nephrotic syndrome of the Finnish type (NPHS1) is an autosomal recessively inherited disorder that is characterized in utero by fetal hydrops. It also presents as nephrotic syndrome in neonates, a progressive disease that leads to massive proteinuria and death during the first two years [1]. This condition was first reported in the Finnish population [2], but it has subsequently been recognized to occur elsewhere. Specifically, by using linkage analysis in a cohort of 17 Finnish families, the genetic locus for this disorder was mapped to 19q12-q13 [3]. The NPHS1 (Nephrosis 1, congenital, Finnish type) gene product Nephrin was subsequently identified as a $180 \mathrm{KD}$ transmembrane protein expressed in glomerular podocytes [1]. Nephrin has also been detected in the pancreas, brain, spinal cord and lymphoid tissues [4], although its role in these tissues has not been identified.

\footnotetext{
* Correspondence: dryoga1@bigpond.com

'Department of Neonatology, The Townsville Hospital, 100 Angus Smith Drive, Douglas, QLD 4814, Australia

${ }^{2}$ Hunter Medical Research Institute, Mothers and Babies Research Centre, John Hunter Hospital, The University of Newcastle, Callaghan, NSW 2310, Australia

Full list of author information is available at the end of the article
}

\section{Nephrinuria and podocytopathies}

Nephrin forms an integral part of podocytes, whichtogether with endothelial cells and the basement-form the glomerular filtration barrier [5]. The filtration barrier consists of a basement membrane, a glomerular endothelial cell monolayer, and a podocyte monolayer on the urinary side [6]. Podocytes have four main functions, which all depend on their unique and specialized architecture. These functions are: the regulation of glomerular permeability selectivity, provision of structural support for the glomerular capillary, remodeling of the glomerular basement membrane (GBM), and endocytosis of filtered proteins $[7,8]$. Podocytes can become injured in human and experimental glomerular diseases and conditions that cause podocyte injuries; these are collectively known as podocytopathies [7]. Pollak et al. proposed the concept of inherited podocytopathies [9]. It is now recognized that the common feature in minimal change disease (MCD), membranous glomerulopathy, crescentic glomerulonephritis, collapsing glomerulopathy, focal segmental glomerulosclerosis (FSGS), diabetic nephropathy, and lupus nephritis is through podocyte damage and dysfunction [10]. Early events in the damaged podocyte are alterations of the slit diaphragm, reorganization of the foot process structure with the fusion of filtration slits, and apical displacement. These preliminary changes may not be visible 
under an optical microscope, necessitating the use of electron microscopy [10]. Early podocyte structural change is characterized by detachment of podocytes from the glomerular basement membrane. These changes can lead to severe and progressive glomerular injuries, if the condition persists. Hence, early recognition of any podocyte injury is of clinical importance.

\section{Methods}

This review is intended to explore aspects associated with the use of Nephrin as a marker in early podocyopathies and it is not the intention of the authors to comment on the molecular function of the protein nephrin. We performed a review of the literature with PubMed, US National Library of Medicine, EMBASE, and The Cochrane Database of Systematic Reviews to determine whether urinary nephrin could be used to detect early glomerular injury. We used the following keywords: nephrinuria, urinary nephrin, microalbuminuria, podocytes, and glomerular injuries. The keywords were searched alone or in combination with other keywords. We reviewed articles published between January 1990 and July 2014. Our search identified a total of 19 studies (6 in animals; 13 in human) that have been published to date. The most common clinical condition in which urinary nephrin analyses were carried out were diabetic nephropathy, glomerulonepharitis, pre-eclampsia, and Systemic Lupus Erythematosus (SLE).

\section{Nephrin measurement}

The most commonly used method for urinary nephrin measurement was with the commercially available ELISA kit ((Exocell, Philadelphia, PA; R\&D Systems, Minneapolis, MN, USA) [11-16]. In one study, the amount of podocyturia was also measured using urinary flow cytometry [17]. Other methods included messenger ribonucleic acid realtime polymerase chain reaction (mRNA RT-PCR) [18-20], electrophoresis [21-25]. In one study, the nature of the analysis was not described [26]. Neprin measurement using a commercially available ELISA kit has increasingly becoming the method of choice for studies conducted since 2012. However, no studies have compared the efficacy of various methods for measuring urinary nephrin. In a few studies, other podocyte protein measurements (Podocalyxin [14] and Podocin [22]) were also carried out concurrently with urinary nephrin but there were no attempts to compare the sensitivity and specificity of these urinary markers to each other.

\section{Animal studies}

Disease models investigated by animal studies can be divided in 2 groups - nephrosis and diabetic nephropathy. In both models, urine nephrin was detected early, prior to significant albuminuria. Luimula et al. carried out a study in which experimental glomerular disease was induced in rats by using puromycin aminonucleoside (PAN) [21]. PAN nephrosis results in effacement and fusion of the podocyte foot processes, leading to the loss of the ultrafiltration barrier, closely resembling the functional and morphologic changes of minimal change disease. The investigators detected nephrin in urine in the peak proteinuric samples and concluded that urinary nephrin is an important marker of proteinuric diseases. The investigators were however unable to determine nephrin's role in this study. In another study [22], the investigators used Heymann nephritis (a widely used experimental model to study idiopathic membranous nephropathy) [27] to induce glomerular injury and to investigate the excretion of urinary nephrin as a result of this injury. The investigators showed that nephrin was excreted into urine during the initial stages of Heymann nephritis, prior to any abnormal albuminuria. However, the investigators from this study did not recognize this nephrinuria as an early sign of glomerular injury and concluded that nephrinuria may have contributed to the development of proteinuria.

Aaltonen et al. investigated the role of nephrin in the pathogenesis of diabetic nephropathy [23]. In this study, the investigators used both the classic streptozotocin (STZ) model of rat diabetes (selectively impairing the insulin production in pancreatic beta cells, mimicking type I diabetes) and spontaneously diabetic non-obese diabetic mice (a model for human insulin-dependent diabetes mellitus). The investigators found that nephrin was detectable in urine of STZ-induced rats at 4 weeks, which then peaked by 6 weeks. Urinary nephrin was detected before the peak in albuminuria and the investigators concluded that nephrin was related to the early changes of diabetic nephropathy. However, again the authors concludedthat the appearance of nephrin in urine contributed to the loss of glomerular function and failed to recognise this as a marker of podocyte injury. In a study by Alter et al., a group of 23 Wistar rats were uninephrectomized and randomly assigned to two groups [28]. The study group received streptozotocin (STZ) to induce diabetes mellitus, whereas the control group received citrate buffer without STZ. Blood glucose levels, blood pressure, kidney function, and weight were then measured. After 18 weeks, blood and urine specimens were collected, and then the animals were euthanized and their organs harvested. The animals in the diabetic group were found to have an elevated glucose level with normal systolic blood pressure. The investigators found that while there were no significant differences in renal function and urinary albumin level between the two groups, the urinary excretion of nephrin was significantly higher in the diabetic group. Nephrin appeared even before albuminuria, leading the study's authors to 
conclude that nephrin measurement in urine offers the possibility for early detection of nephropathy. In another study, Chang et al. demonstrated similar findings in Akita mice (a mouse model of type 1 diabetes mellitus resulting from spontaneous point mutation in the Ins 2 gene) [11]. In this study, the investigators found that urinary nephrin excretion was significantly increased in albuminuria in study of 16 and 20 week old mice and that this correlated with the urinary albumin excretion rate. Enhanced urinary nephrin excretion was shown to be associated with kidney injury and was detected early in the disease process. A similar finding was also reported by O'Brien et al in another study [12]. Table 1 summarizes the animal studies that have been published to date.

\section{Human studies}

Urinary nephrin measurements were carried out in 3 clinical conditions: diabetic nephropathy, nephrosis (including Lupus nephritis) and preeclampsia.

Compared with the animal studies, human studies involved larger sample size but on some occasions there were no control groups [24].

Wang et al carried out a study to investigate the gene expression of podocyte-associated molecules in the urinary sediment of 21 patients with diabetic nephropathy and 9 healthy controls [18]. The investigators found that urinary nephrin levels (measured by mRNA expression) correlated with proteinuria $(\mathrm{r}=0.502, \mathrm{p}=0.020)$ but not with eGFR. Nephrinuria was greater in diabetics with nephropathy, and the investigators concluded that nephrin measurement could play a role in clinical stratification of the patients' diabetic nephropathy. Do Nascimento et al. used mRNA RT-PCR to measure urine nephrin in a cohort of 15 controls and 67 diabetics [19]. The study subjects were assigned to 3 different groups: normoalbuminuria (NO) ( $<30 \mathrm{mg} / \mathrm{g}$ creatinine); microalbuminuria (MI) (30-300 $\mathrm{mg} / \mathrm{g}$ creatinine); and macroalbuminuria (MA) ( $>300 \mathrm{mg} / \mathrm{g}$ creatinine). The investigators found that urine nephrin was higher in diabetics than in non diabetics and correlated with increasing albuminuria. Nephrinuria was found in $53 \%, 71 \%$, and $90 \%$ of NO, MI and MA diabetes subjects, respectively $(\mathrm{p}=0.023)$. The investigators concluded that diabetic subjects had elevated urinary mRNA levels of podocytes protein such as nephrin compared to non- diabetic subjects, even the NO patients. In another study, Patari et al. demonstrated the presence of nephrin fragments using immunohistochemistry and western blotting techniques in the urine of type 1 diabetics with or without nephropathy [25]. The study consisted of five cohorts of patients: 1) diabetic patients with normal albuminuria; 2) diabetics with microalbuminuria; 3) diabetics who had developed microalbuminuria recently; 4) diabetics with macroalbuminuria; and 5) a control group consisting of healthy adults. Micro-albuminuria was defined as a 24-h urinary albumin excretion rate (AER) of 30-300 mg in two of three consecutive 24-h urine collections; macroalbuminuria as an AER of $300 \mathrm{mg} / 24 \mathrm{~h}$; and normoalbuminuria as a persistent AER of $30 \mathrm{mg} / 24 \mathrm{~h}$. The investigators found that nephrinuria was present in $30 \%$ of normoalbuminuric, $17 \%$ of microalbuminuric, $28 \%$ of macroalbuminuric, and $28 \%$ of new microalbuminuric patients; however, none of the control subjects were nephrinuric. The authors concluded that the glomerular filtration barrier may already be compromised in onethird of diabetic patients with nephrinuria.

In a recent study, Jim et al. investigated whether the detection of nephrin in urine can be used as an early biomarker of diabetic nephropathy [13]. Firstly, renal histopathology in a group of 15 patients with type 2 diabetes was compared for the protein expression of nephrin with a group of 12 control patients. This investigation showed the statistically significant down-regulation of podocin and nephrin in kidney biopsies for diabetic nephropathy. Further, analysis of the study group, based on the amount of albumin in urine, detected nephrinuria in $100 \%$ of diabetic patients with micro- and macroalbuminuria and in $54 \%$ of patients with normoalbuminuria. Nephrinuria correlated with albuminuria (rho $=0.89$, $\mathrm{p}=0.001)$ and systolic blood pressure $(\mathrm{rho}=0.32, \mathrm{p}=0.007)$. It also correlated negatively with serum albumin (rho $=$ 20.48, $\mathrm{p}=0.0001)$ and eGFR $(\mathrm{rho}=20.33, \mathrm{p}=0.005)$. The investigators concluded that nephrinuria is a reliable biomarker of preclinical diabetic nephropathy.

In another study, $\mathrm{Ng}$ et al. investigated the association between nephrinuria and various renal traits [24]. This study, which recruited 381 patients with type 2 diabetes mellitus, involved urinary nephrin analysis using electrophoresis and Western blot analysis. The electrophoretic pattern revealed that nephrin was excreted in four distinct protein bands $(25,50,60$ and $75 \mathrm{kDa})$ with the $60 \mathrm{kDa}$ molecule being the most common presentation $(40.7 \%)$. By using regression analysis, the investigators showed that each nephrin fragment was associated with a decrease in eGFR and that nephrinuria was strongly associated with the urine albumin/creatinine ratio. This finding was similar to that of another study involving 70 patients with diabetes mellitus [26].

Proletov et al. investigated daily urinary excretion of nephrin as a possible marker for podocyte apoptosis [29]. In this study, 71 patients with biopsy proven primary glomerulonephritis were recruited. The investigators found that urinary nephrin excretion (using ELISA) correlated well with daily level of proteinuria $(r=0.67$, $\mathrm{p}<0.05$ ). Proteinuria and nephrinuria levels were lower in patients undergoing treatment with cyclosporine. The study showed that the more severe the degree of podocyte injury (as evidenced by increased urinary nephrin), the 
Table 1 Summary of the animal studies that have investigated the relationship between nephrinuria and glomerular injury

\begin{tabular}{|c|c|c|c|c|c|}
\hline Authors & Journal (Year)/PMID & $\begin{array}{l}\text { Study subjects } \\
\text { (sample size N) }\end{array}$ & Disease model & $\begin{array}{l}\text { Method of urine } \\
\text { Nephrin assay }\end{array}$ & Results \\
\hline \multirow[t]{2}{*}{ Luimula et al. } & \multirow[t]{2}{*}{$\begin{array}{l}\text { Pediatric Research } \\
(2000) / 11102543\end{array}$} & Sprague-Dawley rats & \multirow{2}{*}{$\begin{array}{l}\text { Puromycin aminoglycoside (PAN) } \\
\text { induced nephrosis (Minimal change } \\
\text { disease) Effacement and fusion of }\end{array}$} & \multirow[t]{2}{*}{ Electrophoresis } & $\begin{array}{l}\text { 1. Animals treated with puromycin developed albuminuria } \\
\text { starting at day } 3 \text {, and reached maximum at day } 6\end{array}$ \\
\hline & & Control = 6 Study $=12$ & & & $\begin{array}{l}\text { 2. Nephrin can be detected among urinary proteins } \\
\text { when the level of proteinuria exceeds } 25 \mathrm{mg} / \mathrm{mL}\end{array}$ \\
\hline \multirow[t]{3}{*}{ Nakatsue et al. } & \multirow{3}{*}{$\begin{array}{l}\text { Kidney Int. } \\
\text { (2005)/15882266 }\end{array}$} & Wistar rats & \multirow{3}{*}{$\begin{array}{l}\text { Idiopathic membranous } \\
\text { nephropathy (Heymann nephritis) }\end{array}$} & \multirow{3}{*}{$\begin{array}{l}\text { Electrophoresis } \\
\text { (Western blot) }\end{array}$} & \multirow{3}{*}{$\begin{array}{l}\text { 1. Nephrin is excreted into urine in the early stages } \\
\text { of nephritis }\end{array}$} \\
\hline & & Control $=5$ Study $=16$ & & & \\
\hline & & $\begin{array}{l}\text { Sprague-Dawley rats } \\
\text { Control }=3 \text { Study }=3\end{array}$ & & & \\
\hline \multirow[t]{4}{*}{ Aaltonen et al. } & \multirow{4}{*}{$\begin{array}{l}\text { Lab. Invest } \\
(2001) / 11555666\end{array}$} & Wistar rats & \multirow{4}{*}{$\begin{array}{c}\text { Type } 1 \text { (Insulin-dependent) } \\
\text { diabetes mellitus and Diabetic } \\
\text { nephropathy }\end{array}$} & \multirow[t]{4}{*}{ Electrophoresis } & \multirow{2}{*}{$\begin{array}{l}\text { 1. Free nephrin was found in the urine of STZ-induced } \\
\text { rats at } 4 \text { weeks and was at the maximum at } 6 \text { weeks }\end{array}$} \\
\hline & & Control $=3$ Study $=14$ & & & \\
\hline & & Non Obese diabetic mice & & & \multirow{2}{*}{$\begin{array}{l}\text { 2. Nephrin is connected to the early changes of } \\
\text { diabetic nephropathy }\end{array}$} \\
\hline & & Control = 3 Study $=9$ & & & \\
\hline \multirow[t]{2}{*}{ Alter et al. } & \multirow[t]{2}{*}{$\begin{array}{c}\text { Clin.Lab } \\
(2012) / 22997966\end{array}$} & Wistar rats & \multirow{2}{*}{$\begin{array}{c}\text { Streptozotocin (STZ) induced } \\
\text { Diabetes Mellitus and diabetic } \\
\text { nephropathy }\end{array}$} & \multirow[t]{2}{*}{$\begin{array}{l}\text { ELISA (USCN Life Sci. Inc. } \\
\text { Burlington, NC, USA) }\end{array}$} & $\begin{array}{l}\text { 1. Nephrinuria detected prior to albuminuria and } \\
\text { renal impairment. }\end{array}$ \\
\hline & & Control = 9 Study $=14$ & & & $\begin{array}{l}\text { 2. This biomarker offer an advantage to urinary albumin } \\
\text { with respect to early detection }\end{array}$ \\
\hline \multirow[t]{3}{*}{ Chang et al. } & \multirow[t]{3}{*}{$\begin{array}{c}\text { Plos One } \\
(2012) / 22496773\end{array}$} & Akita mice & \multirow[t]{3}{*}{$\begin{array}{l}\text { Type } 1 \text { diabetes mellitus and } \\
\text { diabetic nephropathy }\end{array}$} & \multirow[t]{3}{*}{$\begin{array}{l}\text { ELISA (Exocell, } \\
\text { Philadelphia, PA) }\end{array}$} & $\begin{array}{l}\text { 1. Urinary nephrin excretion is associated with kidney } \\
\text { injury and is detectable early in the disease process. }\end{array}$ \\
\hline & & Control $=8$ Study $=8$ & & & 2. Onset of hyperglycemia associated with nephrinuria \\
\hline & & & & & $\begin{array}{l}\text { 3. Nephrinuria rate has a positive correlation } \\
\text { with albuminuria }\end{array}$ \\
\hline \multirow[t]{2}{*}{ O'Brien et al. } & \multirow{2}{*}{$\begin{array}{l}\text { J of Diabetic Research } \\
\text { (2013)/Not available }\end{array}$} & Mice & \multirow[t]{2}{*}{ Obesity, Type 2 diabetes } & \multirow{2}{*}{$\begin{array}{l}\text { ELISA (Exocell, } \\
\text { Philadelphia, PA) }\end{array}$} & \multirow[t]{2}{*}{ 1. Nephrinuria correlates with albuminuria } \\
\hline & & Control = 12 Study = 12 & & & \\
\hline
\end{tabular}


Table 2 Summary of the human studies

\begin{tabular}{|c|c|c|c|c|c|}
\hline Authors & Journal (Year)/PMID & $\begin{array}{l}\text { Study sample } \\
\text { size }\end{array}$ & Clinical condition & $\begin{array}{l}\text { Method of urine } \\
\text { Nephrin assay }\end{array}$ & Results \\
\hline \multirow[t]{2}{*}{ Patari et al. } & \multirow[t]{2}{*}{ Diabetes (2003)/14633858 } & Control = 29 & \multirow[t]{2}{*}{ Diabetic Nephropathy } & \multirow[t]{2}{*}{$\begin{array}{l}\text { Electrophoresis } \\
\text { (Western blot) }\end{array}$} & $\begin{array}{l}\text { 1. Nephrinuria was present in } 30 \% \text { of normoalbuminuric, } 17 \% \text { of } \\
\text { microalbuminuric, } 28 \% \text { of macroalbuminuric, }\end{array}$ \\
\hline & & Study $=120$ & & & 2. None of the control subjects was nephrinuric. \\
\hline \multirow[t]{2}{*}{ Wang et al. } & \multirow[t]{2}{*}{$\begin{array}{l}\text { Nephron Clin Pract. } \\
\text { (2007)/17596726 }\end{array}$} & Control = 9 & \multirow[t]{2}{*}{ Diabetic nephropathy } & \multirow[t]{2}{*}{ mRNA RT-PCR } & $\begin{array}{l}\text { 1. Nephrinuria higher in patients with diabetic nephropathy compared } \\
\text { to control. }\end{array}$ \\
\hline & & Study $=21$ & & & 2. Nephrinuria correlated with proteinuria \\
\hline \multirow[t]{3}{*}{$\mathrm{Ng}$ et al. } & \multirow{3}{*}{$\begin{array}{l}\text { Nephrol. Dial.Transplant } \\
(2011) / 21196468\end{array}$} & \multirow[t]{3}{*}{ Study $=381$} & \multirow[t]{3}{*}{ Diabetic nephropathy } & \multirow{3}{*}{$\begin{array}{l}\text { Electrophoresis } \\
\text { (Western blot) }\end{array}$} & 1. Each Nephrin fragment was associated with a decline in eGFR \\
\hline & & & & & $\begin{array}{l}\text { 2. Nephrinuria was strongly associated with the urine } \\
\text { albumin/creatinine ratio }\end{array}$ \\
\hline & & & & & $\begin{array}{l}\text { 3. Nephrinuria was significantly associated with lower eGFR even among } \\
\text { normoalbuminuric patients ( } A C R \leq 30 \mathrm{mg} / \mathrm{g} \text { ) }\end{array}$ \\
\hline \multirow[t]{4}{*}{ Jim et al. } & \multirow[t]{4}{*}{ PLoS ONE (2012)/22615747 } & Control = 12 & \multirow[t]{4}{*}{ Diabetic nephropathy } & \multirow{4}{*}{$\begin{array}{l}\text { ELISA (Exocell, } \\
\text { Philadelphia, PA) }\end{array}$} & 1. Nephrinuria preceded microalbumniuria \\
\hline & & Study $=15$ & & & $\begin{array}{l}\text { 2. Nephrinuria detected in all diabetic patients with micro and } \\
\text { macroalbuminuria }\end{array}$ \\
\hline & & & & & $\begin{array}{l}\text { 3. Nephrinuria also correlated significantly with albuminuria and } \\
\text { systolic blood pressure }\end{array}$ \\
\hline & & & & & 4. Correlated negatively with serum albumin and eGFR \\
\hline \multirow[t]{2}{*}{ do Nascimento et al. } & \multirow[t]{2}{*}{ BMC Nephrol.(2013)/24103534 } & Control $=15$ & \multirow[t]{2}{*}{ Diabetic Nephropathy } & \multirow[t]{2}{*}{ mRNA RT-PCR } & $\begin{array}{l}\text { 1. Normoalbuniuric diabetics showed increased urinary nephrin compared } \\
\text { to control group }\end{array}$ \\
\hline & & Study $=67$ & & & 2. Nephrinuria correlated with diabetic nephropathy stages \\
\hline \multirow[t]{2}{*}{ Petrica et al. } & \multirow{2}{*}{$\begin{array}{l}\text { *Nephrology Dialy.Transpl } \\
\text { (2014)/NA }\end{array}$} & Control = 11 & \multirow[t]{2}{*}{ Diabetic nephropathy } & \multirow[t]{2}{*}{ NA } & 1. Urine albumin creatinine ratio correlates with nephrinuria \\
\hline & & Study $=70$ & & & $\begin{array}{l}\text { 2. Increased levels of urinary nephrin in normoalbuminuric and } \\
\text { microalbuniuruc patients }\end{array}$ \\
\hline \multirow[t]{3}{*}{ Wang et al. } & \multirow[t]{3}{*}{ J Rheumatol (2007)/17985404 } & Control $=17$ & \multirow{3}{*}{$\begin{array}{l}\text { Systemic Lupus } \\
\text { Errythematosus (SLE) }\end{array}$} & \multirow[t]{3}{*}{ mRNA RT-PCR } & 1. Nephrinuria higher in patients SLE nephritis \\
\hline & & Study $=32$ & & & 2. Nephrinuria correlated with proteinuria \\
\hline & & & & & 3. Nephrinuria level correlated with severity of SLE disease activity \\
\hline \multirow[t]{2}{*}{ Tchebotareva et al. } & \multirow{2}{*}{$\begin{array}{l}\text { *Nephrology Dialy.Transpl } \\
\text { (2012)/NA }\end{array}$} & Study $=74$ & \multirow[t]{2}{*}{ Glomerulonephritis } & \multirow[t]{2}{*}{ ELISA } & 1. Nephrinuria correlated with proteinuria and severity of GN \\
\hline & & & & & 2. Immunosuppressive therapy lowers nephrinuria levels \\
\hline \multirow[t]{2}{*}{ Proletov et al. } & *Nephrology Dialy.Transpl & Study = 71 & Glomerulonephritis & ELISA & 1. Nephrinuria correlated with daily proteinuria \\
\hline & $(2 U / 4) / / N A$ & & & & $\begin{array}{l}\text { 2. Nephrinuria and proteinuria lowest excretion in patients treated } \\
\text { with Cyclosporine. }\end{array}$ \\
\hline Mehta et al. & *AJKD (2012)/NA & Control $=14$ & Preeclampsia & ELISA (Exocell, & 1. Urine nephrin to creatinine ratio (UNCR) are predictive of preeclampsia \\
\hline & & Study $=67$ & & & \\
\hline
\end{tabular}


Table 2 Summary of the human studies (Continued)

\begin{tabular}{|c|c|c|c|c|c|}
\hline \multirow[t]{3}{*}{ Wang et al. } & \multirow[t]{3}{*}{$\begin{array}{l}\text { Am J Physiol Renal Physiol } \\
\text { (2012)/22301621 }\end{array}$} & Control = 8 & \multirow[t]{3}{*}{ Preeclampsia } & \multirow[t]{3}{*}{$\begin{array}{l}\text { ELISA (Exocell, } \\
\text { Philadelphia, PA) }\end{array}$} & $\begin{array}{l}\text { 1. Urinary Nephrin and podocalyxin concentrations were significantly } \\
\text { increased and highly correlated with each other in preeclampsia }\end{array}$ \\
\hline & & \multirow[t]{2}{*}{ Study $=26$} & & & $\begin{array}{l}\text { 2. Nephrin and podocalyxin were also correlated with urine protein } \\
\text { concentrations in preeclampsia }\end{array}$ \\
\hline & & & & & 3. Nephrin undetectable in normal pregnancy \\
\hline \multirow[t]{3}{*}{ Son et al. } & \multirow{3}{*}{$\begin{array}{l}\text { Eur J Obstet Gynecol Reprod Biol. } \\
\qquad(2013) / 23116596\end{array}$} & Control $=30$ & \multirow[t]{3}{*}{ Preeclampsia } & \multirow{3}{*}{$\begin{array}{l}\text { ELISA (R\&D Systems, } \\
\text { Minneapolis, MN, USA) }\end{array}$} & 1. Nephrin was significantly higher in women with severe pre-eclampsia \\
\hline & & \multirow[t]{2}{*}{ Study $=43$} & & & 2. Positive correlation between urinary nephrin and urine protein level \\
\hline & & & & & $\begin{array}{l}\text { 3. Urine nephrin concentrations correlated with diastolic blood pressure } \\
\text { and serum creatinine levels in the severe pre-eclamptic group }\end{array}$ \\
\hline \multirow[t]{2}{*}{ Jim et al. } & \multirow[t]{2}{*}{ PLOS ONE (2014)/25010746 } & Control $=13$ & Preeclampsia & \multirow{2}{*}{$\begin{array}{l}\text { ELISA (Exocell, } \\
\text { Philadelphia, PA) }\end{array}$} & \multirow{2}{*}{$\begin{array}{l}\text { 1. Alb/Cr ratio had a high specificity }(96 \%) \text {. All three biomarkers exhibited } \\
\text { poor positive predictive values (14-62\%) but acceptable negative } \\
\text { predictive values ( } 89-91 \%) \text {. }\end{array}$} \\
\hline & & Study $=78$ & & & \\
\hline
\end{tabular}


worse the level of proteinuria. Response to treatment is evidenced by not only a decrease in urinary protein levels, but also nephrin excretion. In another very similar study, urine nephrin levels in a cohort of 74 adults with chronic glomerulonephritis were measured, and the investigators found that urine nephrin level exhibited a positive correlation with the severity of the disease and proteinuria [17]. Urine nephrin measurement has also been used in studies involving patients with lupus nephritis (LN) [20]. In this study, a group of 49 (32 with active LN and 17 in remission) patients with LN were recruited. mRNA was used determine urine nephrin levels, and the researchers found that it was elevated in the active group and showed a positive correlation with proteinuria $(\mathrm{r} 0.480, \mathrm{p}<0.01)$. The authors concluded that urinary nephrin quantification could play a role in the clinical classification of patients with LN.

More recently, urinary nephrin analyses have been used to monitor pre-eclampsia and pregnancy-induced hypertension. Wang et al. investigated the role of podocyte protein shedding in pre-eclampsia, recruiting 34 pregnant women and dividing them into three groups (normotensive, chronic hypertension, and pre-eclampsia) [14]. Clinical information such as weight, blood pressure, and gestation was recorded, and urine creatinine, albumin, and nephrin were analyzed. The investigators found that nephrin was barely detectable in the urine specimens of normal pregnant women and of those that had chronic hypertension. In pre-eclamptic patients, however, urinary nephrin concentrations were significantly increased. These results provide strong evidence that podocyte protein shedding occurs in pre-eclampsia at levels that correlate with proteinuria. In another study, Son et al. compared urine excretion in a cohort of pregnant women with severe pre-eclampsia compared with normotensive pregnant women [30]. The investigators found urinary nephrin to be significantly higher in women with severe pre-eclampsia and a positive correlation between urinary nephrin and urine protein level. Urine nephrin concentrations also correlated with diastolic blood pressure and serum creatinine levels in the severe pre-eclamptic group. The investigators concluded that urinary nephrin excretion plays a critical role in the pathogenesis of proteinuria during pre-eclampsia and that it is a good indicator of renal damage. A similar conclusion was also made in another study by Mehta et al. of 67 high-risk obstetric patients [15]. In a more recent study, Jim et al. found the sensitivity and specificity for nephrinuria in detecting pre-eclampsia to be only $57 \%$ and 58\%, respectively [16]. Table 2 summarizes human studies on nephrin measurement published to date.

\section{Conclusion}

Currently, urine micro-albuminuria is used as an early indicator of glomerular injury. Both animal and human studies have demonstrated that nephrinuria occurs early in glomerular injury, preceding albuminuria, and that there is a positive correlation with severity of renal diseases. Neprin detection in urine may also have role in early detection of severe pre-eclampsia. Urine nephrin analysis thus has the potential to become an important biomarker of early glomerular injury. To date, no studies on children or adolescents have been published, pointing to a need for clinical studies using urinary nephrin to assess, monitor, and prognosticate renal diseases in children.

\section{Competing interests}

The authors declare that they have no competing interests.

\section{Authors' contributions}

All four authors contributed equally in preparation of this manuscript. All authors read and approved the final manuscript.

\section{Author details}

'Department of Neonatology, The Townsville Hospital, 100 Angus Smith Drive, Douglas, QLD 4814, Australia. ' Hunter Medical Research Institute, Mothers and Babies Research Centre, John Hunter Hospital, The University of Newcastle, Callaghan, NSW 2310, Australia. ${ }^{3}$ College of Public Health, Medical and Veterinary Sciences, The James Cook University, Townsville, QLD 4814, Australia.

Received: 26 August 2014 Accepted: 7 November 2014 Published: 23 November 2014

\section{References}

1. Kestila M, Lenkkeri U, Mannikko M, Lamerdin J, McCready P, Putaala H, Ruotsalainen V, Morita T, Nissinen M, Herva R, Kashtan CE, Peltonen L, Holmberg C, Olsen A, Tryggvason K: Positionally cloned gene for a novel glomerular protein-nephrin-is mutated in congenital nephrotic syndrome. Mol Cell 1998, 1:575-582.

2. Norio R: Heredity in the congenital nephrotic syndrome. A genetic study of 57 finnish FAMILIES WITH A REVIEW OF REPORTED CASES. Ann Paediatr Fenn 1966, 12(27):21-94.

3. Kestila M, Mannikko M, Holmberg C, Gyapay G, Weissenbach J, Savolainen ER, Peltonen L, Tryggvason K: Congenital nephrotic syndrome of the Finnish type maps to the long arm of chromosome 19. Am J Hum Genet 1994, 54:757-764.

4. Astrom E, Rinta-Valkama J, Gylling M, Ahola H, Miettinen A, Timonen T, Holthofer H: Nephrin in human lymphoid tissues. Cell Mol Life Sci 2006, 63:498-504.

5. Brinkkoetter PT, Ising C, Benzing T: The role of the podocyte in albumin filtration. Nat Rev Nephrol 2013, 9:328-336.

6. Welsh Gl, Saleem MA: Nephrin-signature molecule of the glomerular podocyte? J Pathol 2010, 220:328-337.

7. Barisoni L, Mundel P: Podocyte Biology and the Emerging Understanding of Podocyte Diseases. Am J Nephrol 2003, 23:353-360.

8. Barisoni L, Schnaper HW, Kopp JB: A Proposed Taxonomy for the Podocytopathies: A Reassessment of the Primary Nephrotic Diseases. Clin J Am Soc Nephrol 2007, 2:529-542.

9. Pollak MR: Inherited Podocytopathies: FSGS and Nephrotic Syndrome from a Genetic Viewpoint. J Am Soc Nephrol 2002, 13:3016-3023.

10. Camici M: Urinary biomarkers of podocyte injury. Biomark Med 2008, 2:613-616.

11. Chang JH, Paik SY, Mao L, Eisner W, Flannery PJ, Wang L, Tang Y, Mattocks N, Hadjadj S, Goujon JM, Ruiz P, Gurley SB, Spurney RF: Diabetic kidney disease in FVB/NJ Akita mice: temporal pattern of kidney injury and urinary nephrin excretion. PLoS One 2012, 7:e33942.

12. O'Brien SP, Smith M, Ling H, Phillips L, Weber W, Lydon J, Maloney C, Ledbetter S, Arbeeny C, Wawersik S: Glomerulopathy in the KK.Cg-Ay/J Mouse Reflects the Pathology of Diabetic Nephropathy. J Diabetes Res 2013, 2013:13 
13. Jim B, Ghanta M, Qipo A, Fan Y, Chuang PY, Cohen HW, Abadi M, Thomas DB, He JC: Dysregulated nephrin in diabetic nephropathy of type 2 diabetes: A cross sectional study. PLoS One 2012, 7(5):e36041.

14. Wang Y, Zhao S, Loyd S, Groome L: Increased urinary excretion of nephrin, podocalyxin, and (beta)ig-h3 in women with preeclampsia. Am J Physiol Ren Physiol 2012, 302:F1084-F1089.

15. Mehta S, Qipo A, Sharma S, Acharya A, Jim B: Urinary albumin vs. urinary nephrin in predicting the development of preeclampsia. Am J Kidney Dis 2012, 59:A56.

16. Jim B, Mehta S, Qipo A, Kim K, Cohen HW, Moore RM, He JC, Sharma S: A comparison of podocyturia, albuminuria and nephrinuria in predicting the development of preeclampsia: a prospective study. PLoS One 2014, 9:e101445.

17. Tchebotareva N, Bobkova I, Kozlovskaya L, Li O, Eskova O, Shvetsov M, Golytsina E, Varshavskiy V, Popova O: Assessment of podocyte dysfunction and urinary podocyte loss in chronic glomerulonephritis (CGN): Significance for estimation of clomerular damage and glomerulosclerosis risk. Nephrol Dial Transplant 2012, 27:ii195.

18. Wang G, Lai FM, Lai KB, Chow KM, Li KT, Szeto CC: Messenger RNA expression of podocyte-associated molecules in the urinary sediment of patients with diabetic nephropathy. Nephron Clin Pract 2007. 106:C169-c179.

19. Do Nascimento JF, Canani $L H$, Gerchman F, Rodrigues PG, Joelsons $G$, Dos Santos M, Pereira S, Veronese FV: Messenger RNA levels of podocyteassociated proteins in subjects with different degrees of glucose tolerance with or without nephropathy. BMC Nephrol 2013, 14(8):214.

20. Wang G, Lai FMM, Tam LS, Li KM, Lai KB, Chow KM, Li KTP, Szeto CC: Messenger RNA expression of podocyte-associated molecules in urinary sediment of patients with lupus nephritis. J Rheumatol 2007, 34:2358-2364.

21. Luimula P, Aaltonen P, Ahola H, Palmen T, Holthofer H: Alternatively spliced nephrin in experimental glomerular disease of the rat. Pediatr Res 2000, 48:759-762.

22. Nakatsue T, Koike H, Han GD, Suzuki K, Miyauchi N, Yuan H, Salant DJ, Gejyo F, Shimizu F, Kawachi H: Nephrin and podocin dissociate at the onset of proteinuria in experimental membranous nephropathy. Kidney Int 2005, 67:2239-2253.

23. Aaltonen P, Luimula P, Astrom E, Palmen T, Gronholm T, Palojoki E, Jaakkola I, Ahola $\mathrm{H}$, Tikkanen I, Holthofer $\mathrm{H}$ : Changes in the expression of nephrin gene and protein in experimental diabetic nephropathy. Lab Invest 2001, 81:1185-1190

24. Ng DPK, Tai BC, Tan E, Leong H, Nurbaya S, Lim XL, Chia KS, Wong CS, Lim $W Y$, Holthofer $\mathrm{H}$ : Nephrinuria associates with multiple renal traits in type 2 diabetes. Nephrol Dial Transplant 2011, 26:2508-2514.

25. Patari A, Forsblom C, Havana M, Taipale H, Groop PH, Holthofer H: Nephrinuria in Diabetic Nephropathy of Type 1 Diabetes. Diabetes 2003, 52:2969-2974

26. Petrica L, Vlad A, Gluhovschi G, Gadalean F, Dumitrascu V, Gluhovschi C, Velciov S, Bob F, Vlad D, Popescu R, Petrica M, Jianu DC, Milas O, Izvernari O, Ursoniu S: Proximal tubule dysfunction is associated with urinary nephrin and vascular endothelial growth factor excretion in normoalbuminuric type 2 diabetes mellitus patients: Across-sectional study. Nephrol Dial Transplant 2014, 29:iii420-iii421.

27. Salant DJ, Quigg RJ, Cybulsky AV: Heymann nephritis: mechanisms of renal injury. Kidney Int 1989, 35:976-984.

28. Alter ML, Kretschmer A, Von Websky K, Tsuprykov O, Reichetzeder C, Simon A, Stasch JP, Hocher B: Early Urinary and Plasma Biomarkers for Experimental Diabetic Nephropathy. Clinical Laboratory 2012, 58:659-671.

29. Proletov I, Galkina O, Bogdanova E, Zubina I, Sipovskii V, Smirnov A: Clinical significance of podocyte injury markers evaluation in patients with primary glomerulopathies. Nephrol Dial Transplant 2014, 29:iii193.

30. Son GH, Kwon JY, Lee S, Park J, Kim YJ, Yun B, Park JH: Comparison of serum and urinary nephrin levels between normal pregnancies and severe preeclampsia. Eur J Obstet Gynecol Reprod Biol 2013, 166:139-144.

doi:10.1186/2050-7771-2-21

Cite this article as: Kandasamy et al: Nephrin - a biomarker of early glomerular injury. Biomarker Research 2014 2:21.

\section{Submit your next manuscript to BioMed Central and take full advantage of:}

- Convenient online submission

- Thorough peer review

- No space constraints or color figure charges

- Immediate publication on acceptance

- Inclusion in PubMed, CAS, Scopus and Google Scholar

- Research which is freely available for redistribution 